\title{
PSYCHOLOGICAL, SOCIAL AND EMOTIONAL WELL-BEING OF ADULTS WITH A HISTORY OF INSTITUTIONALIZATION: THE PILOT STUDY FINDINGS
}

\author{
M.A. CHUMAKOVA ${ }^{\mathrm{a}}$, M.A. ZHUKOVA ${ }^{\mathrm{b}, \mathrm{e}}$, S.A. KORNILOV ${ }^{\mathrm{c}}$, \\ I.V. GOLOVANOVA ${ }^{\mathrm{b}}$, A.O. DAVYDOVA ${ }^{\mathrm{b}}$, T.I. LOGVINENKO ${ }^{\mathrm{b}}$, \\ I.V. OVCHINNIKOVA ${ }^{\mathrm{b}}$, M.V. PETROV ${ }^{\mathrm{d}}$, A.V. ANTONOVA ${ }^{\mathrm{a}}$, \\ O.YU. NAUMOVA ${ }^{\mathrm{e}, \mathrm{f}}$, E.L. GRIGORENKO ${ }^{\mathrm{b}, \mathrm{e}}$
}

\author{
${ }^{a}$ National Research University Higher School of Economics, 20 Myasnitskaya Str., Moscow, 101000, \\ Russian Federation \\ ${ }^{b}$ Saint Petersburg State University, 7/9 Universitetskaya emb., Saint Petersburg, 199034, Russian \\ Federation \\ ${ }^{c}$ Institute for Systems Biology, 401 Terry Avenue North, Seattle, WA 98109-5263, USA \\ ${ }^{d}$ Kashchenko Psychiatric Hospital, 10 Menkovskaya St., Nikolskoye Village, Gatchinsky District, \\ Leningrad Region, 88357, Russian Federation \\ ${ }^{e}$ University of Houston, 3695 Cullen blvd, Houston, TX 77204-5022, USA \\ ${ }^{f}$ Vavilov Institute of General Genetics, RAS, 3 Gubkina St., GSP-1 Moscow, 119991, Russian Federation
}

\begin{abstract}
The paper presents pilot research data that is part of the research project "The Impact of Early Deprivation on the Bio-Behavioral Indicators of Child Development" from the Government's megagrant programs No. 14.Z50.31.0027. The purpose of the paper is the study of mental, social and emotional well-being indicators of adults raised in orphanages in comparison with a control group of adults who grew up in biological families. The comparison was carried out using scales of the WHO Questionnaire for assessing quality of life and Adult Self-Report (ASR) from The Achenbach System of Empirically Based Assessment (ASEBA) for assessing psychological and emotional well-being. Results revealed no significant differences between the groups studied. However, using the classification procedures, we found that an important feature is the living conditions that enable classification of membership in a group of graduates of an orphanage or in a group of adults from biological families: a separate apartment or a "public" space (a communal apartment or a dorm). A hypothesis has been put forward about the impact of the current living environment on the diagnosed indicators of the mental, social and emotional well-being of orphanage graduates.
\end{abstract}

Keywords: orphans, orphanage, mental, social and emotional well-being.

The study was supported by the grant from the Government of the Russian Federation № 14.Z50.31.0027. 


\section{Introduction}

According to survey data collected in the Russian Federation, many children with a history of institutional placement (in orphanages or baby homes) experience problems with social adaptation, due to a lack of social skills and emotion regulation (Bobyleva, 2007). It has been shown that children currently residing in orphanages (Pastukhova, 2011), as well as children who have graduated from and left orphanages (Prisyazhnaya, 2007), experience problems with social adaptation. Children in this group show an increased prevalence of internalizing problems (e.g., aloofness, fear of being alone) and attachment disturbances. Adults with a history of institutionalization often experience problems with employment because of low working motivation; they also demonstrate high rates of substance abuse (Sem'ya, 2007).

The detrimental psychological effects of being raised in institutions without parental care have been vastly discussed and investigated world-wide (e.g., Bos et al., 2011; Erol, Öztop, \& Özcan, 2008; Groze \& Ileana, 1996; Merz \& McCall, 2010). It has been shown that children and adolescents raised in institutions exhibit marked deficits across a number of developmental domains compared to agematched children raised in family settings. These include cognitive, affective, and behavioral difficulties and higher rates of such disorders as anxiety, depression, ADHD and conduct disorder (Bos et al., 2011; Erol et al., 2008; Merz \& McCall, 2010).

Factors that may influence or contribute to these social maladaptations may include strict routines within the institution, lack of interaction with caregivers, and restricted social activities (Shulga, 2011). These factors contribute to dependent behavior and insecurities about the future, resulting in difficulty in forming and maintaining social connections for adults with a history of institutionalization.

Despite the importance of social adaptation for children and adolescents raised in institutional care, there is currently a dearth of research on the long-lasting residual effects of institutional placement on the life course of orphanage graduates who are actively engaged in social life. This lack of empirical data may be partially explained by the difficulty of organizing such studies: the recruitment of participants is challenging due to the stigma surrounding orphanage graduates; this label holds negative connotations that lead to many concealing their life stories. In addition, information is legally restricted in the Russian Federation concerning adoption and institutional placement.

The long-term impact of institutionalization is a serious concern as people with a history of institutional care (IC) face possible exclusion from social life (Bakhmatova \& Chusova, 2013). As a group, adults with a history of institutionalization are characterized by higher, compared to baseline, unemployment rates and criminal records (Sem'ya, 2007). Focus groups have identified the following factors that potential employers reported about adults with an IC history: lack of social skills (passive or aggressive attitudes towards peers; abuse of welfare benefits; avoiding responsibility or shifting responsibility; and substance abuse). In turn, according to surveys conducted with adults with an IC history, these adults perceive employers to have unrealistic expectations, believe they are being treated unequally as a socially disadvantaged group, and report that they are negatively 
labeled as poor or thieves or delinquents (Ibid.). Thus, employers avoid employing individuals who have an IC history, and people with an IC history are not looking for full-time jobs; this makes social adaptation for adults with an IC challenging (Bakhmatova \& Chusova, 2013).

To address this problem a number of policies have been introduced in Russia aimed at increasing the social adaptation of people with an IC history (Sem'ya, 2007). Yet, these policies are not evidence-based, as this group of adults is poorly represented in the research literature (Shulga, 2011). The lack of empirical data on adults with an IC history is evident not only in Russia, but also elsewhere in the world. Institutional care is a common solution for abandoned children in Eastern Europe, the Middle East, as well as from African and Asian countries. Although IC is rarely observed in North America and Western Europe, that is where the overwhelming majority of scientific research on the role of IC in human well-being is taking place. Therefore, most of the data regarding children growing up without their biological parents is derived from studies investigating the effects of foster/adoption family transition - the most common solution for orphans or abandoned children in North American and Western European countries - on children's developmental outcomes (e.g., Dubois-Comtois et al., 2015; Ferrari, Vezzali, \& Rosnati, 2017; Piermattei, Pace, Tambelli, D’Onofrio, \& Di Folco, 2017).

A Canadian study investigated adults with a history of IC placement, i.e., the physical and mental health of adults in psychiatric institutions who were raised in orphanages (Sigal, Perry, Rossignol, \& Ouimet, 2003). The study included men and women ranging from 43 to 73 years of age, who were placed in an institution at an early age (mean age at institutional placement was 5 years, however the majority of respondents were institutionalized right after birth). The indicators of their physical and mental health were compared to a randomly selected representative sample of Quebec residents. The results showed that adults with an IC history had lower educational attainment and marriage rate than their community peers and, in general, lived more isolated lives. These adults, in comparison to the general population, reported chronic stress-related diseases more often (e.g., depression, allergies), however, there were no actual differences in the rates of chronic illness. Yet, although psychological distress and suicidal thoughts (and attempts) were more frequently observed in adults with an IC history, no statistical differences in self-perceived quality of life were identified.

Another study, conducted in Germany, aimed at understanding the relationship between the conditions of adolescence (foster care vs institutional placement) and attachment patterns in adulthood (Nowacki \& Schoelmerich, 2010). Results showed that adults raised in foster families demonstrated more secure attachment patterns than adults raised in institutions. In addition, the study illustrated that adults with an IC history had elevated and close to clinical threshold indicators of psychological stress.

There is also some data on the long-term effects of institutionalization. Specifically, data was collected from 100 girls who were internationally adopted from institutions in Hong Kong to Great Britain in the 1960s (Rushton, Grant, Feast, \& Simmonds, 2013). All of the girls were institutionalized prior to adoption 
for an average of 3 months. Data was collected when the women were 42-53 $(\mathrm{M}=48)$ years of age. Comparison groups from the community as well as women who were born and adopted within Great Britain were studied. No statistical differences were found between the groups in their rates of mental health difficulties, marriage and divorce rates, and emotional support from others. The authors of the study speculated that if the institutional experience is long-term, but interrupted by adequate care, the IC experience per se does not elevate the risk for mental and physical health issues in adulthood. These findings have been interpreted as evidence of the potential longitudinal remediation of IC effects during the course of life.

In the English Romanian Adoptee Study (ERA), where the residual effects of IC history in internationally adopted Romanian orphans were investigated, the higher prevalence of attention deficits and hyperactivity in adolescence with an IC history was identified (Kennedy et al., 2016; Rutter et al., 2010). Participants were divided into two groups: individuals who had experienced short-term institutionalization, and those who had experienced long-term deprivation (children adopted by British families right after birth or who had lived in Romanian orphanages less than 6 months, and children who had been residing in Romanian institutions from 6 to 43 months). Data was collected from the participants at two age points: at 15, then 22-25 years of age. Results showed that the institutionalization effect was more pronounced for hyperactivity and attention deficits during adolescence (i.e., at the age of 15), however, in individuals who had experienced long-term institutionalization, these indicators were critical at both time points. In sum, it has been shown that institutional care has detrimental long-lasting effects on specific aspects of cognitive and social-emotional development lasting into adulthood.

In 2017, a large Australian study was published (Fernandez et al., 2017) that included 669 adults ranging from 27 to 100 years who had experienced IC. Most of the participants $(\sim 60 \%)$ had accommodation problems in adulthood (were homeless or resided in shelters), and more than $1 / 3$ reported having criminal records. More than $50 \%$ of participants had problems coping with stress, or reported having mental health problems and relationship issues.

Based on the empirical data reported above, it can be concluded that a history of IC may have long-lasting effects, contributing to higher stress levels and somatic problems, as well as difficulty with attention and hyperactivity. Yet, other data suggests that an IC history can be remediated over the course of life and does not have to leave a traumatic footprint on development. Given such mixed results, it is evident that further empirical data is required in order to learn more about the residual effects of institutionalization.

It is also noteworthy that apart from the social adaptation issues present in adults with an IC history, there is a societal bias in attitudes toward adults with an IC history. According to sociological surveys, the mass media in Russia has created two positive and two negative images of people with IC histories that are very simplified and stereotypical (Abramov \& Antonova, 2017): "the positive independent type" (the self-made character); "positive passive" (lacking a sense of agency), "negative independent" (a deviant trouble maker) and "negative passive" (socially stigmatized) (Ibid., p. 421). This study shows that the "passive" stereotypes are 
mostly spread and perpetuated by the mass media, whereas the "independent" types are rarely discussed. This tendency can have negative effects on potential employers, teachers, and romantic partners, who as a result develop a bias towards people with an IC history.

In sum, the literature on the long-term impact of IC is both limited in size and inconsistent in findings; clearly, more research is needed to increase its volume and resolve its inconsistencies. This article presents pilot data from a study aimed at assessing the psychological, social and emotional well-being of people with a history of institutionalization compared to a group of peers raised in biological families.

\section{Sample}

The sample consisted of 58 participants ranging from 16 to 37 years of age $(\mathrm{Med}=20$, $\mathrm{M}=21.81, \mathrm{SD}=5.77)$ :

People with a history of institutionalization (institutional care, IC): 27 respondents ( 8 females and 19 males);

Control group of individuals raised in biological families (biological families, BF): 31 participants (13 females and 18 males).

The IC group was recruited in colleges of secondary education and vocational training schools with a structural unit for children left without parental care, as well as through cooperation with charitable foundations involved in helping orphanage graduates. Leaflets with an invitation to participate in the study were distributed in those organizations. All participants were pre-screened for neurological diagnoses and sensory deficits. Only those participants who reported no diagnoses or had corrected sensory deficits (i.e., were wearing glasses) were included in the study. The duration of institutionalization differed within the group and ranged from 2 to 18 years $(\mathrm{Med}=10, \mathrm{M}=9.33, \mathrm{SD}=4.61)$. The control group (BF) was recruited using the same protocol in the same educational institutions as well as through announcements on social media in the Internet. The BF group was recruited to match the IC group on the level of education. Most of the participants in both groups had secondary education ( 9 grades -17 people: 12 in the IC and 5 in the $\mathrm{BF}$ ), vocational training or were high school graduates (10-11 grades 34 people: 14 in the IC and 20 in the BF). In the BF group, 2 people had less than 9 grades of education and 4 were college students or graduates. In the IC group 1 participant had a $\mathrm{PhD}$ degree. Along with data on their education levels, demographic data regarding marital status, children and accommodation (i.e., living situation, private versus communal) was also collected.

\section{Procedure and methods}

In order to evaluate the psychological, social and emotional well-being of the participants, two self-report questionnaires were used: The Achenbach System of Empirically Based Assessment (ASEBA) and the World Health Organization Quality of Life Questionnaire (WHOQOL-BREF). 
We used the Russian version of the ASEBA obtained from the official distributor of the Achenbach questionnaire in Russia (H. Slobodskaya'). The ASEBA contains a list of questions aimed at evaluating adaptive behavior, social functioning, and maladaptive behavior patterns (Achenbach \& Rescorla, 2003). Clinical syndromes measured by the ASEBA align with the DSM-4 (Achenbach, Dumenci, \& Rescorla, 2003; Kornilova, Grigorenko, \& Smirnov, 2005). This is one of the most reliable and comprehensive instruments that measures psychological and social well-being and has been previously used with a subpopulation of teenagers with IC histories (e.g., Escobar, Pereira, \& Santelices, 2014; Roskam et al., 2014; Surugiu \& Moşoiu, 2013).

The ASEBA scales include: (1) Adaptive functioning: the Adaptive Functioning Profile that includes items capturing levels of competence in dealing with Friends, Spouse/Partner, Family, Job, and Education; (2) Clinical scales: Anxious/Depressed, Withdrawn, Somatic Complaints, Thought Problems, Attention Problems, Aggressive Behavior, Rule-Breaking Behavior, and Intrusive Behavior; (3) Substance use scale. The reliability of the ASEBA scales for the Russian version was verified as part of its cross-cultural validation (Ivanova et al., 2015). Confirmatory factor analysis showed that the original factor structure of the questionnaire was replicated in the Russian sample (RAMSEA $=0.027, \mathrm{CFI}=0.881$, TLI $=0.878$, Median loading $=0.60$ ).

The WHOQL-BREF is a self-report form developed by the World Health Organization to evaluate self-perceived life quality that can be compared cross-culturally (WHOQOL Group, 1998). It contains the following scales (with internal consistency for the Russian sample shown by Cronbach's in a multicultural study): Physical Health (0.83), Psychological Health (0.79), Social Relationships (0.74), and Environment (0.80) (Skevington, Lotfy, \& O'Connell, 2004).

Prior to data analysis, the ASEBA raw scores were transformed into standardized T-scores $(\mathrm{M}=50, \mathrm{SD}=10)$ as suggested by the ASEBA Manual (Achenbach \& Rescorla, 2003) using mean and standard deviation of the control group raw scores as a reference. The WHOQL-BREF raw scores were transformed into standardized WHOQL scores using WHOQL Manual (Murphy, Herrman, Hawthorne, Pinzone, \& Evert, 2000).

\section{Results}

In the statistical analysis we used data from participants with complete secondary education to avoid differences linked with the education level. The final sample included 51 participants: the IC group - 26 people ( 7 females and 19 males), the BF group - 25 people ( 9 females and 16 males). No significant differences in terms of age distribution between the two groups were detected $(t(\mathrm{df})=0.020(47.577)$, $p=0.984)$ ), nor in the gender distribution $\left(\chi^{2}(\mathrm{df})=0.157(1), p=0.692\right)$.

The analysis was aimed at comparing the IC and BF groups based on the ASEBA and WHOQL-BREF questionnaires. We used Student's $t$-test to compare

\footnotetext{
${ }^{1}$ http://www.aseba.org/ordering/distributors.html\#russia
} 
mean group values. Considering that 19 variables were compared, the Holm method of multiple comparisons adjustment was applied. Analysis was carried out using $\mathrm{R}$.

The analyses yielded no statistically significant group differences in the ASEBA questionnaire, nor in the WHOQL-BREF (see Table 1). Figure 1 and 2 present distributions for all of the variables of interest among the IC and BF groups.

In order to get more detailed results about the characteristics of the psychological, social and emotional well-being of adults with IC histories, we used a classification tree method (James, Witten, Hastie, \& Tibshirani, 2013). This method helps to create a step-by-step classification based on predictors, and to attribute observations to given classes (the dependent variable). In our study the parameters of classification were indicators of psychological, social and emotional well-being, and the predicted class - the group variable (whether the subject belonged to the IC

Table 1

Results of the Group Comparison

\begin{tabular}{|c|c|c|c|c|c|c|}
\hline Scale & IC: M (SD) & BF: M (SD) & $t(\mathrm{df})$ & $p$ & $\operatorname{adj} . p$ & Cohen's d \\
\hline \multicolumn{7}{|c|}{ ASEBA scales } \\
\hline Adaptiveness & $47.69(6.98)$ & $50.04(7.02)$ & $-1.20(49)$ & 0.237 & 1.000 & 0.336 \\
\hline Substance Use & $51.52(7.67)$ & $49.87(6.02)$ & $0.82(46)$ & 0.414 & 1.000 & 0.293 \\
\hline Anxious/Depressed & $45.54(6.92)$ & $49.34(9.88)$ & $-1.53(46)$ & 0.133 & 1.000 & 0.446 \\
\hline Withdrawn & $50.69(8.11)$ & $48.66(9.64)$ & $0.79(47)$ & 0.431 & 1.000 & 0.228 \\
\hline Somatic Complaints & $44.59(8.54)$ & 48.04 (8.98) & $-1.36(46)$ & 0.180 & 1.000 & 0.394 \\
\hline Thought Problems & $45.42(7.08)$ & $49.36(10.61)$ & $-1.52(47)$ & 0.134 & 1.000 & 0.437 \\
\hline Attention Problems & $47.58(9.07)$ & $49.50(10.28)$ & $-0.69(47)$ & 0.493 & 1.000 & 0.198 \\
\hline Aggressive Behavior & $45.42(6.77)$ & $48.40(9.21)$ & $-1.29(47)$ & 0.204 & 1.000 & 0.369 \\
\hline Rule-Breaking Behavior & $46.98(8.03)$ & $49.64(10.8)$ & $-0.98(47)$ & 0.334 & 1.000 & 0.280 \\
\hline Intrusive & $45.33(9.89)$ & $49.96(9.97)$ & $-1.67(49)$ & 0.102 & 1.000 & 0.466 \\
\hline Other Problems & $41.80(8.55)$ & $49.58(10.07)$ & $-2.87(46)$ & 0.006 & 0.117 & 0.833 \\
\hline Internalization & $46.04(7.83)$ & $48.66(9.64)$ & $-1.03(46)$ & 0.310 & 1.000 & 0.298 \\
\hline Externalization & $45.35(8.18)$ & $49.08(10.08)$ & $-1.42(47)$ & 0.163 & 1.000 & 0.406 \\
\hline Additional Problems & $43.96(8.35)$ & $49.34(10.55)$ & $-1.95(46)$ & 0.057 & 1.000 & 0.565 \\
\hline Total Problems Score & $44.72(7.92)$ & $48.94(10.13)$ & $-1.60(46)$ & 0.117 & 1.000 & 0.464 \\
\hline \multicolumn{7}{|c|}{ WHOQL-BREF } \\
\hline Physical Health & $15.62(1.58)$ & $16.20(1.96)$ & $-1.18(49)$ & 0.245 & 1.000 & 0.326 \\
\hline Psychological Health & $14.38(2.35)$ & $15.40(1.98)$ & $-1.67(49)$ & 0.102 & 1.000 & 0.469 \\
\hline Social Relationships & $14.42(3.64)$ & $14.84(2.79)$ & $-0.46(49)$ & 0.649 & 1.000 & 0.130 \\
\hline Environment & $13.81(2.47)$ & $14.32(2.41)$ & $-0.75(49)$ & 0.457 & 1.000 & 0.209 \\
\hline
\end{tabular}

* ASEBA scale means for the BF group diverge from 50 (mean for T-scores) due the exclusion of $6 \mathrm{BF}$ participants from the statistical analysis 
Figure 1

Social and Emotional Well-Being in the IC and BF Groups' ASEBA Scales

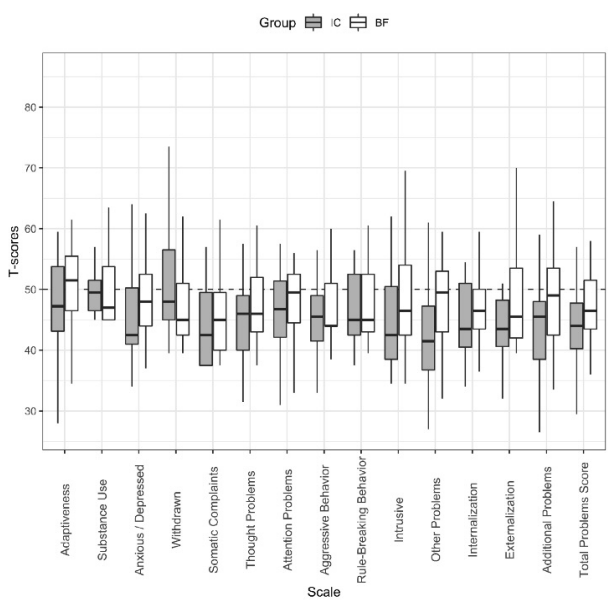

Figure 2

Social and Emotional Well-Being in the IC and BF Groups' WHOQL-BREF Scales

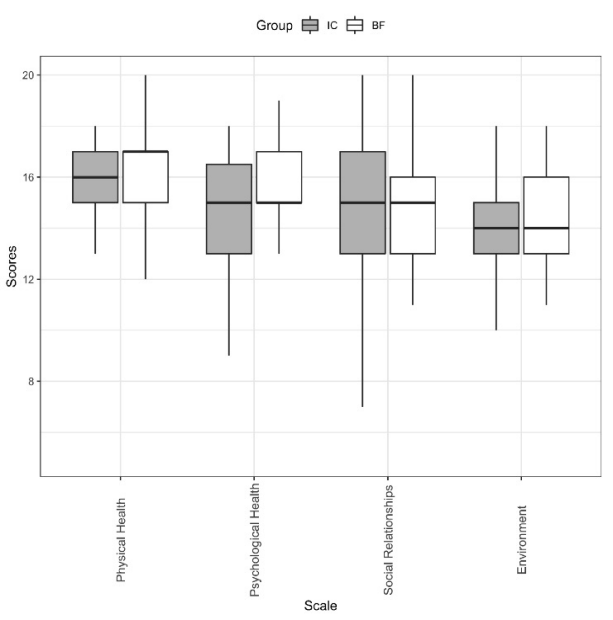

or BF group). To summarize, the aim of the analysis was to find a configuration of test variables that would accurately predict which group a participant belongs to.

We considered primary values from the ASEBA questionnaire as potential predictors of group membership (IC or BF). As additional potential predictors we used demographic data about marital status, children, and accommodation, as they reflect the actual life status of study participants and can impact the questionnaire data. Only full cases where all indicator-predictor data was available were used for the classification - 46 cases in total (23 in each group).

The analysis was carried out in $\mathrm{R}$ using a tree package: Classification and Regression Trees (Ripley, 2016). The resulting classification tree had a low error rate of group belonging identification - 9\% (4 cases out of 46 were incorrectly classified: 2 subject from the BF group and 2 subjects in the IC group). The following predictors were used for the classification: Accommodation, Withdrawn, Attention problems, Environment and Physical Health. The results of the classification are presented in Figure 3.

As evident in Figure 3, the primary parameter for classification was the participant's accommodation. Based on this classification, people with an IC history can be characterized according to the following (compared to control group):

- When living in a private apartment, people with an IC history demonstrate higher levels of Withdrawn, and rate environmental well-being higher than the BF group;

- When living in communal apartments or dorms, people with an IC history

- Either demonstrate lower levels of Attention problems than subjects in the BF group,

- Or do not differ from the BF group in the rate of Attention problems, but report lower physical health compared to peers in the control group. 


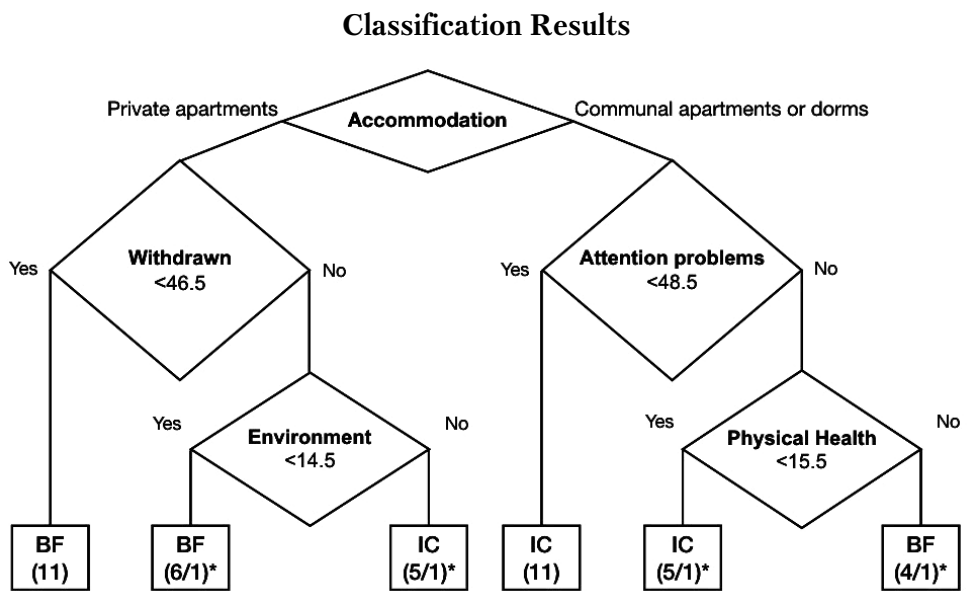

Figure 3

Note. The number in brackets corresponds to the number of participants in the subgroup; * indicates errors in classification: $\mathrm{BF}(6 / 1)^{*}$ means that the model correctly classifies 6 subjects in the BF group and 1 in the IC group.

\section{Discussion}

We did not find any significant differences in the indicators of psychological, social and emotional well-being between adults with a history of institutionalization and peers from the control group raised in biological families. Although preliminary, our results suggest that the social adaptation of people with an IC history is more successful than their cognitive development and language development. Our results are in agreement with the study that demonstrated no statistically significant differences in indicators of mental and physical health between adults with an IC history and those without it (Rushton et al., 2013).

We demonstrated that the social adaption of adults with an IC history is characterized by lower scores on all scales except Substance Use and Withdrawn (in terms of ASEBA scales). In other words, adults who were raised in biological families seem to have poorer adaptive skills than people with an IC history who graduated from an orphanage. This finding leads us to three contradicting hypotheses that need further investigation.

Hypothesis 1 . These findings are reliable and there are no statistically significant group differences in the psychological, social and emotional well-being between adults with and without a history of institutionalization. This finding needs replication on a larger sample, which is currently being recruited.

Hypothesis 2. The absence of group differences may be attributed to the lack of self-reflection in adults with an IC history that is indirectly supported by significantly lower IQ scores in this group compared to a control group (based on the CFIT). We suggest the following mediating mechanism: people with lower IQs have less awareness regarding their behavior patterns that yields lower problem behavior scores on the ASEBA. This hypothesis contradicts results obtained in the 
Canadian study (Sigal et al., 2003) of higher rates of self-reported chronic stressrelated diseases in adults with a history of IC placement. Nevertheless we assume that cognitive deficits might affect performance on standardized written questionnaires.

Hypothesis 3. Given their life history, adults with a history of institutionalization might deliberately report fewer problem behaviors than their age-peers in order to present a more socially acceptable profile.

Thus, in formulating such hypotheses it is important to consider the results of the classification procedure conducted during this pilot study. Findings show that accommodation is an important classification parameter: a private apartment or a communal space - a communal apartment or a dorm. This finding suggests an additional hypothesis about the impact of the current environment on psychological, social and emotional well-being. Adults with a history of institutionalization who live in private apartments are exposed to less familiar (albeit comfortable) conditions. This subgroup demonstrates higher levels of social isolation than adults raised in biological families. This can be explained by the possible lack of experience in building social networks in adults with an IC history, as most of their social activities were shared only with peers living in the same institution.

As for the adults with an IC history who live in communal apartments or dorms, an important classification indicator was the Attention Problems indicator, with equal or lower scores compared to adults without an IC history. We suggest that this differences can be explained by the fact that communal living is a familiar accommodation for people with an IC history, whereas for adults raised in biological families, cohabiting with peers in communal apartments might be frustrating and stressful, which may lead to attention problems in the control group.

Compared to previously published results about the transition of orphanage graduates to adulthood (Fernandez et al., 2017), we need to emphasize that all our IC participants were recruited in a large city through announcements in different organizations and social networks on the Internet. So our participants represent a group that had opportunities to receive government and charity support. Moreover, most of them were college students using accommodation benefits provided by the educational institution. Thus they did not report any difficulties with their accommodations, unlike the participants in earlier research (Ibid.).

In conclusion, our findings suggest that there is no evidence of lower psychological, social and emotional well-being of adults with a history of institutionalization. Likely, the occurrence of these indicators is linked to history of institutionalization as well as to current life circumstances. We are currently continuing to collect data to better characterize and understand social adaptation and the psychological problems of adults with an IC history.

We are grateful to Matilda Marie Steele of the University of Durham, UK and Mei Tan of the University of Houston, USA for their editorial help. 


\section{References}

Abramov, R. N., \& Antonova, K. A. (2017). Social adaptation among graduates from orphanages in the Russian media: A thematic analysis of publications for 2014-2015. Zhurnal Issledovanii Sotsial'noi Politiki, 15(3), 421-434. (in Russian)

Achenbach, T. M., Dumenci, L., \& Rescorla, L. (2003). Ratings of relations between DSM-IV diagnostic categories and items of the Adult Self-Report (ASR) and Adult Behavior Checklist (ABCL). Retrieved from http://www.aseba.com/research/dsm-adultratings.pdf

Achenbach, T. M., \& Rescorla, L. A. (2003). Manual for the ASEBA Adult Forms \& F Profiles. Burlington, VT: University of Vermont, Research Center for Children, Youth, \& Families.

Bakhmatova, T. G., \& Chusova, Y. A. (2013). Analysis of orphans' exclusion on labour market. Baikal Research Journal, 3, 24. Retrieved from http://brj-bguep.ru/reader/article.aspx?id=18121 (in Russian)

Bobyleva, I. A. (2007). Sotsialnaya adaptatsiya vypusknikov internatnykh uchrezhdenii [Social adaptation of graduates of orphanage institutions]. Moscow: Natsional'nyi fond zashchity detei ot zhestokogo obrashcheniya. (in Russian)

Bos, K., Zeanah, C. H., Fox, N. A., Drury, S. S., McLaughlin, K. A., \& Nelson, C. A. (2011). Psychiatric outcomes in young children with a history of institutionalization. Harvard Review of Psychiatry, 19(1), 15-24. doi:10.3109/10673229.2011.549773

Dubois-Comtois, K., Bernier, A., Tarabulsy, G. M., Cyr, C., St-Laurent, D., Lanctot, A. S., ... Beliveau, M. J. (2015). Behavior problems of children in foster care: Associations with foster mothers' representations, commitment, and the quality of mother-child interaction. Child Abuse and Neglect, 48, 119-130. doi:10.1016/j.chiabu.2015.06.009

Erol, N., Öztop, D., \& Özcan, Ö. Ö. (2008). [Epidemiology of emotional and behavioral problems in children and adolescents reared in orphanages: a national comparative study]. Türk Psikiyatri Dergisi [Turkish Journal of Psychiatry], 19(3), 235-246. (in Turkish)

Escobar, M. J., Pereira, X., \& Santelices, M. P. (2014). Behavior problems and attachment in adopted and non-adopted adolescents. Children and Youth Services Reviez, 42, 59-66.

Fernandez, E., Lee, J.-S., Foote, W., Blunden, H., McNamara, P., Kovacs, S., Cornefert, P.-A. (2017). 'There's more to be done; "Sorry" is just a word': Legacies of out-of-home care in the 20th century. Children Australia, 42(3), 176-197.

Ferrari, L., Vezzali, L., \& Rosnati, R. (2017). The role of adoptive parents' intergroup contact in fostering the well-being of adoptees: The "extended intragroup contact effect". International Journal of Intercultural Relations, 59, 43-52. doi:10.1016/j.jintrel.2017.04.014

Groze, V., \& Ileana, D. (1996). A follow-up study of adopted children from Romania. Child and Adolescent Social Work Journal, 13(6), 541-565.

Ivanova, M. Y., Achenbach, T. M., Rescorla, L. A., Turner, L. V., Ahmeti-Pronaj, A., Au, A., ... Chen, Y.C. (2015). Syndromes of self-reported psychopathology for ages 18-59 in 29 societies. Journal of Psychopathology and Behavioral Assessment, 37(2), 171-183.

James, G., Witten, D., Hastie, T., \& Tibshirani, R. (2013). An introduction to statistical learning. New York: Springer.

Kennedy, M., Kreppner, J., Knights, N., Kumsta, R., Maughan, B., Golm, D., ... Sonuga Barke, E. J. (2016). Early severe institutional deprivation is associated with a persistent variant of adult attention deficit/hyperactivity disorder: clinical presentation, developmental continuities and life 
circumstances in the English and Romanian adoptees study. Journal of Child Psychology and Psychiatry, 57(10), 1113-1125.

Kornilova, T. V., Grigorenko, E. L., \& Smirnov, S. D. (2005). Podrostki grupp riska [Adolescents at risk]. Saint Petersburg: Piter. (in Russian)

Merz, E. C., \& McCall, R. B. (2010). Behavior problems in children adopted from psychosocially depriving institutions. Journal of Abnormal Child Psychology, 38(4), 459-470.

Murphy, B., Herrman, H., Hawthorne, G., Pinzone, T., \& Evert, H. (2000). The World Health Organization Quality of Life (WHOQOL) Study: Australian WHOQOL-100, WHOQOL-BREF and $C A-W H O Q O L$ instruments user's manual and interpretation guide. Melbourne: WHOQOL Field Study Centre, Department of Psychiatry, University of Melbourne and St Vincent's Mental Health Service.

Nowacki, K., \& Schoelmerich, A. (2010). Growing up in foster families or institutions: Attachment representation and psychological adjustment of young adults. Attachment and Human Development, 12(6), 551-566.

Pastukhova, D. A. (2011). Experimental study of psychological adaptation of preschool and primary school age orphans. Vestnik Buryatskogo gosudarstvennogo universiteta [Bulletin of the Buryat State University], 5, 206-210. (in Russian)

Piermattei, C., Pace, C. S., Tambelli, R., D’Onofrio, E., \& Di Folco, S. (2017). Late adoptions: Attachment security and emotional availability in mother-child and father-child dyads. Journal of Child and Family Studies, 26(8), 2114-2125. doi:10.1007/s10826-017-0732-6

Prisyazhnaya, N. V. (2007). Orphan children: Entering life after graduation. Sotsiologicheskie Issledovaniya, 11, 54-63. (in Russian)

Ripley, B. (2016). tree: Classification and Regression Trees. Retrieved from https://cran.rproject.org/web/packages/tree/index.html

Roskam, I., Stievenart, M., Tessier, R., Muntean, A., Escobar, M. J., Santelices, M., ... Pierrehumbert, B. (2014). Another way of thinking about ADHD: the predictive role of early attachment deprivation in adolescents' level of symptoms. Social Psychiatry and Psychiatric Epidemiology, 49(1), 133-144.

Rushton, A., Grant, M., Feast, J., \& Simmonds, J. (2013). The British Chinese Adoption Study: Orphanage care, adoption and midlife outcomes. Journal of Child Psychology and Psychiatry, 54(11), 1215-1222.

Rutter, M., Sonuga-Barke, E. J., Beckett, C., Castle, J., Kreppner, J., Kumsta, R., ... Gunnar, M. R. (2010). Deprivation-specific psychological patterns: Effects of institutional deprivation. Boston, MA/Oxford, UK: Wiley-Blackwell.

Sem'ya, G. V. (2007). Rossiyskiy opyt raboty s vypusknikami internatnykh uchrezhdeniy [The Russian experience with graduates of orphanage institutions]. Nevolya, 14. Retrieved from http://www.index.org.ru/nevol/2007-14/15_semya_n14.html

Shulga, T. I. (2011). Social and psychological problems of orphanage graduates and children left without parental care. Vestnik Moskovskogo gosudarstvennogo oblastnogo universiteta: elektronnyi jurnal [Bulletin of Moscow State Regional University: Electronic Journal], 4, 85-95. (in Russian)

Sigal, J. J., Perry, J. C., Rossignol, M., \& Ouimet, M. C. (2003). Unwanted infants: Psychological and physical consequences of inadequate orphanage care 50 years later. American Journal of Orthopsychiatry, 73(1), 3-12. 
Skevington, S. M., Lotfy, M., \& O'Connell, K. A. (2004). The World Health Organization's WHOQOL-BREF quality of life assessment: psychometric properties and results of the international field trial. A report from the WHOQOL group. Quality of Life Research, 13(2), 299-310.

Surugiu, S. I., \& Moşoiu, C. (2013). The aggressive behavior of adolescents in institutionalized system. Procedia-Social and Behavioral Sciences, 78, 546-550.

WHOQOL Group. (1998). Development of the World Health Organization WHOQOL-BREF quality of life assessment. Psychological Medicine, 28(3), 551-558.

Maria A. Chumakova - Associate Professor, School of Psychology, Department of Social Sciences, National Research University Higher School of Economics, PhD in Psychology.

Research Area: risk and decision-making, individual differences in decision-making and attitudes towards uncertainty, intelligence and executive functions, neurobiological correlates of cognitive development.

E-mail: mchumakova@hse.ru

Marina A. Zhukova - Research Fellow, Laboratory for Interdisciplinary Development Studies, St. Petersburg State University; Research assistant, Department of Psychology, University of Houston (Houston, USA), PhD in Psychology.

Research Area: clinical psychology, language and speech development, cognitive development, EEG, environmental impact on human development, institutionalization.

E-mail: zhukova.marina.spb@gmail.com

Sergey A. Kornilov - Senior Research Fellow, Institute for Systems Biology (Seattle, USA), $\mathrm{PhD}$ in Psychology.

Research Area: polygenic modeling, complex traits, neuroimaging, psychometrics.

Irina V. Golovanova - Junior Research Fellow, Laboratory for Interdisciplinary Development Studies, St. Petersburg State University, PhD in Psychology.

Research Area: psychophysiology, EEG, thinking, intelligence, language, speech.

E-mail: ir.golovanova@gmail.com

Aleksandra O. Davydova - Laboratory Assistant, Laboratory for Interdisciplinary Development Studies, St. Petersburg State University.

Research Area: socio-emotional development of young children.

E-mail: aleksandradavydova.spb@gmail.com

Tatiana I. Logvinenko - Research Engineer, Laboratory for Interdisciplinary Development Studies, St. Petersburg State University.

Research Area: developmental psychology, neurobiology of language and speech, reading and writing disorders.

E-mail: logvinenkota.spb@gmail.com

Irina V. Ovchinnikova - Junior Research Fellow, Laboratory for Interdisciplinary Development Studies, St. Petersburg State University.

Research Area: development disorders.

E-mail: ovchinir@gmail.com

Maksim V. Petrov - Medical Psychologist, Kashchenko Psychiatric Hospital, PhD in Psychology.

Research Area: neuropsychology, cognitive neurophysiology, clinical neuroscience.

E-mail: petrov_m@list.ru 
Anna V. Antonova - Lecturer, School of Psychology, Department of Social Sciences, National Research University Higher School of Economics, PhD.

Research Area: developmental psychology, educational psychology.

E-mail: annantonova@gmail.com

Oksana Y. Naumova - Senior Research Fellow, Vavilov Institute of General Genetics, RAS; Research Assistant Professor, Department of Psychology, University of Houston (Houston, USA), PhD in Biology.

Research Area: genetics, epigenetics, genomics.

E-mail: oksana.yu.naumova@gmail.com

Elena L. Grigorenko - Professor, Lead Scientist, Laboratory for Interdisciplinary Development Studies, St. Petersburg State University; Professor, Department of Psychology, University of Houston (Houston, USA), Doctor of Psychology, PhD.

Research Area: studying developmental obstacles, child development.

E-mail: elena.grigorenko@yale.edu

\title{
Психологическое, социальное и эмоциональное благополучие взрослых с опытом институционализации: результаты пилотного исследования
}

\author{
М.А. Чумакова ${ }^{a}$, М.А. Жукова ${ }^{\mathrm{b}, \mathrm{e}}$, С.А. Корнилов ${ }^{\mathrm{c}}$, И.В. Голованова ${ }^{\mathrm{b}}$, А.О. Давыдова \\ Т.И. Логвиненко ${ }^{\text {, }}$, И.В. Овчинникова ${ }^{\mathrm{b}}$, М.В. Петров ${ }^{\mathrm{d}}$, А.В. Антонова ${ }^{\mathrm{a}}$, О.Ю. Наумова ${ }^{\mathrm{e}, \mathrm{f}}$, \\ Е.Л. Григоренко ${ }^{\text {be }}$
}

${ }^{a}$ Национальный исследовательский университет «Высшая школа экономики», 101000, Россия, Москва, ул. Мясницкая, д. 20

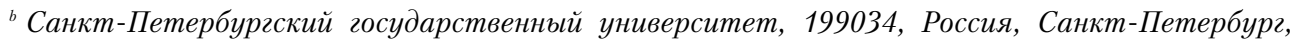
Университетская наб., д. 7/9

${ }^{c}$ Институт системной биологии, 401 Terry Avenuе North, Seattle, WA 98109-5263, USA

${ }^{d}$ СПб ГБУЗ «Больнища им. П.П. Кащенко», Россия, 88357, Ленинградская обл., Гатчинский p-н, с. Никольское, ул. Меньковская, Ә. 10

е Университет г. Хьюстон, 3695 Cullen blvd, Houston, TX 77204-5022, USA

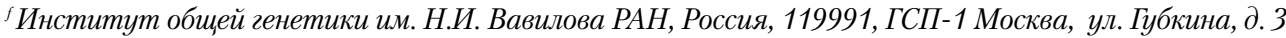

\section{Резюме}

В статье представлены пилотные данные исследования, являющегося частью исследовательского проекта «Влияние ранней депривации на биоповеденческие показатели развития ребенка», осуществляемого в рамках программы мегагрантов Правительства РФ № 14.Z50.31.0027. Цель статьи - изучение показателей психического, социального и эмоционального благополучия взрослых с опытом институционализации в сравнении с контрольной группой взрослых, выросших в биологических семьях. Сравнение проводилось по шкалам Опросного листа Ахенбаха и краткого опросника ВОЗ для оценки качества жизни. Значимых различий по шкалам опросников между группой выпускников детских домов и контрольной группой обнаружено не было. Однако при использовании процедур классификации было установлено, что важным признаком, позволяющим классифицировать 
принадлежность к группе выпускников детского дома или к группе взрослых из биологических семей, являются условия проживания: отдельная квартира или «общественное» пространство - коммунальная квартира или общежитие. Выдвинута гипотеза о влиянии актуальной жизненной среды на диагностируемые показатели психического, социального и эмоционального благополучия выпускников интернатных учреждений.

Ключевые слова: сироты, детский дом, психическое, социальное и эмоциональное благополучие.

Чумакова Мария Алексеевна - доцент, департамент психологии, факультет социальных наук, Национальный исследовательский университет «Высшая школа экономики», кандидат психологических наук.

Сфера научных интересов: психология риска и принятия решений, индивидуальные различия в принятии решений и отношении к неопределенности, интеллект и исполнительные функции, нейробиологические корреляты когнитивного развития.

Контакты: mchumakova@hse.ru

Жукова Марина Андреевна - научный сотрудник, лаборатория междисциплинарных исследований развития человека, Санкт-Петербургский государственный университет; исследователь, факультет психологии, Университет г. Хьюстон (Хьюстон, США), кандидат психологических наук.

Сфера научных интересов: детская клиническая психология, развитие языка и речи, когнитивное развитие, ЭЭГ, влияние среды на развитие человека, институционализация.

Контакты: zhukova.marina.spb@gmail.com

Корнилов Сергей Александрович - старшиий научныи сотрудник, Институт системной биологии (Сиэтл, США), кандидат психологических наук, PhD.

Сфера научных интересов: полигенное моделирование, комплексные черты, нейровизуализация, психометрика.

Голованова Ирина Валерьевна - младший научный сотрудник, лаборатория междисциплинарных исследований развития человека, Санкт-Петербургский государственный университет, кандидат психологических наук.

Сфера научных интересов: психофизиология, ЭЭГ, мышление, интеллект, язык, речь.

Контакты: ir.golovanova@gmail.com

Давыдова Александра Олеговна - лаборант-исследователь, лаборатория междисциплинарных исследований развития человека, Санкт-Петербургский государственный университет. Сфера научных интересов: социально-эмоциональное развитие детей раннего возраста. Контакты: aleksandradavydova.spb@gmail.com

Логвиненко Татьяна Игоревна - инженер-исследователь, лаборатория междисциплинарных исследований развития человека, Санкт-Петербургский государственный университет. Сфера научных интересов: психология развития, нейробиология языка и речи, нарушения чтения и письма.

Контакты: logvinenkota.spb@gmail.com

Овчинникова Ирина Викторовна - младший научный сотрудник, лаборатория междисциплинарных исследований развития человека, Санкт-Петербургский государственный университет.

Сфера научных интересов: расстройства развития.

Контакты: ovchinir@gmail.com 
Петров Максим Владимирович - медицинский психолог, СПб ГБУЗ «Больница им. П.П. Кащенко», кандидат психологических наук.

Сфера научных интересов: нейропсихология, когнитивная нейрофизиология, клиническая нейронаука.

Контакты: petrov_m@list.ru

Антонова Анна Валерьевна - преподаватель, департамент психологии, факультет социальных наук, Национальный исследовательский университет «Высшая школа экономики», $\mathrm{PhD}$.

Сфера научных интересов: психология развития, психология образования.

Контакты: annantonova@gmail.com

Наумова Оксана Юрьевна - старший научный сотрудник, Институт общей генетики им. Н.И. Вавилова РАН; доцент-исследователь, факультет психологии, Университет г. Хьюстон (Хьюстон, США), кандидат биологических наук.

Сфера научных интересов: генетика, эпигенетика, геномика.

Контакты: oksana.yu.naumova@gmail.com

Григоренко Елена Леонидовна - профессор, ведущий ученый лаборатории междисциплинарных исследований развития человека, Санкт-Петербургский государственный университет, доктор психологических наук; профессор, факультет психологии, Университет г. Хьюстон (Хьюстон, США), доктор психологических наук, $\mathrm{PhD}$.

Сфера научных интересов: изучение препятствий развития, развитие ребенка.

Контакты: elena.grigorenko@yale.edu 